\title{
The impact of Iranian EFL university students' personality type on their burnout
}

\author{
Ali Roohani, Yeganeh Esmaeili \& Masoud Rahimi Domakani \\ Shahrekord University
}

(Text received 09 September 2017; accepted 25 July 2018; final version 29 September 2018)

DOI: http://doi.org/10.5565/rev/jtl3.742

\begin{abstract}
Burnout is a three dimensional phenomenon which is categorized as an important social problem. Personality type is also an important factor that may play a role in developing burnout. However, research has focused on job burnout, environmental factors, and their impacts on people and society and there is not much research related to student burnout and the impact of individual factors on student burnout. Thus, this study investigated the impact of EFL students' personality type on their burnout. For data collection, the Myers-Briggs Type Indicator (MBTI) and Maslach Burnout InventoryStudent Survey (MBI-SS) were given to a sample of 292 Iranian EFL students from several universities. The results indicated that there was a significant difference between extrovert-introvert and sensingintuition groups in three components of burnout (emotional exhaustion, depersonalization, and personal accomplishment). Moreover, there was a significant difference between the judging-perceiving group in emotional exhaustion and depersonalization dimensions but, there was not a significant difference between them in the personal accomplishment dimension. Besides, there was not any significant difference in the thinking-feeling group in three dimensions of burnout. The findings can give EFL teachers and students the power to predict which students will be more at risk for burnout and help them to prevent burnout.
\end{abstract}

Keywords: burnout, personality type, academic year of study

Resum: El "burnout" (o síndrome d'esgotament professional) és un fenomen tridimensional considerat un problema social important. El tipus de personalitat és un factor important en el desenvolupament de l'esgotament professional. La recerca s'ha centrat en l'esgotament laboral, els factors ambientals i l'impacte que té en les persones i la societat i no hi ha gaire recerca relacionada amb el l'esgotament dels estudiants i l'impacte que hi tenen els factors individuals. Així, aquest estudi explora la influència que el tipus de personalitat d'estudiants d'EFL té en el seu esgotament psicològic. Per a la recopilació de dades, l'indicador de Myers-Briggs (MBTI) i l'enquesta de Maslach (MBI-SS) es van lliurar a una mostra de 292 estudiants d'EFL iranians de diverses universitats. Els resultats indiquen que hi ha una diferència significativa entre grups segons els criteris extravertit/introvertit i sensorial/intuïtiu pel que fa a tres components del "burnout" (esgotament emocional, despersonalització i realització personal). A més, hi ha una diferència significativa pel que fa al grup valoratiu/perceptiu en relació a l'esgotament emocional i les dimensions lligades a la despersonalizació, però no una diferència significativa en aquest grup en la dimensió de la realització personal. A més, no hi ha una diferència significativa en el grup reflexiu/emocional en tres dimensions de burnout. Les troballes poden donar als professors $i$ als estudiants d'EFL la capacitat de predir quins estudiants tindran més risc d'esgotar-se acadèmicament $i$ ajudar-los a prevenir aquesta situació.

Paraules clau: burnout, tipus de personalitat, curs acadèmic d'estudi

Resumen: El "burnout" (o "síndrome de agotamiento profesional") es un fenómeno tridimensional considerado un problema social importante. El tipo de personalidad es un factor importante en el desarrollo del agotamiento profesional. La investigación se ha centrado en el agotamiento laboral, los factores ambientales y el impacto que tiene en las personas y la sociedad y no hay mucha investigación relacionada con el agotamiento de los estudiantes y el impacto que tienen los factores individuales. Así, este estudio explora la influencia que el tipo de personalidad de estudiantes de EFL tiene en su agotamiento psicológico. Para la recopilación de datos, el indicador de Myers-Briggs (MBTI) y la 
encuesta de Maslach (MBI-SS) fueron implementados en una muestra de 292 estudiantes de EFL iraníes de varias universidades. Los resultados indican que hay una diferencia significativa entre grupos según los criterios extrovertido/introvertido y sensorial/intuitivo con respecto a tres componentes del "burnout" (agotamiento emocional, despersonalización y realización personal). Además, hay una diferencia significativa con respecto al grupo valorativo/perceptivo en relación al agotamiento emocional y las dimensiones relacionadas con la despersonalización, pero no hay una diferencia significativa en este grupo en la dimensión de la realización personal. Además, no hay una diferencia significativa en el grupo reflexivo/emocional en tres dimensiones de burnout. Los hallazgos pueden dar a los profesores y los estudiantes de EFL la capacidad de predecir qué estudiantes tendrán más riesgo de agotarse académicamente y ayudarles a prevenir esta situación.

Palabras clave: burnout, tipo de personalidad, curso académico de estudi

\section{Introduction}

Anxiety and stress are two important factors that can affect students' learning and achievement. Those students who learn English as a foreign language (EFL) can experience language anxiety more because of some psychological, social and cultural factors (Khattak, Jamshed, Ahmad, \& Baig, 2011). Due to these problems, burnout in EFL students is more common than in other students. Maslach (1982) defines burnout as "a psychological syndrome involving emotional exhaustion, depersonalization, and a diminished sense of personal accomplishment that occurred among people in challenging situations" (p. 4). Emotional exhaustion represents the individuals' stress level. It is described as "feelings of being emotionally overextended and depleted of one's emotional resources” (Maslach, 1993, p. 22). Depersonalization is the interpersonal component of burnout and appears in response to the emotional exhaustion. It is delineated as "a negative, callous, or excessively detached response to various aspects of the job" (Maslach, 2015, p. 930). The reduced efficacy or personal accomplishment presents the self-evaluation level of burnout. It refers to a person's feelings of incompetence and a lack of successful achievement in his/her work (Maslach, 1993).

Students' burnout is one important factor that has serious impacts on their lives and learning. Yang (2004) states that students in the learning process facing course stress, heavy course load or other psychological factors, display a state of emotional exhaustion, a tendency to depersonalization, and a feeling of low personal accomplishment. Students' burnout can lead to higher absenteeism, lower motivation, and higher percentage of drop out (Ramist, 1981).

Furthermore, personality type is one important factor that may contribute to burnout. Mayer (2007) defined personality as "a system of parts that is organized, develops, and is expressed in a person's actions" (p. 1). Dennis (2008) states that conceptual differences in 
personality type can play a role in motivation, social interaction, and behavioral outcomes. Some studies (e.g., Braden, 1995; Greenberg et al., 2003; Higgins, Peterson, \& Pihl, 2007; McPherson, 1999; Noftle \& Robins, 2007) have focused on the effect of personality on education. These studies show that personality can affect students' behavior and learning, but no study has so far made an attempt to study the effect of Iranian EFL university students' personality type on their experiences of burnout.

According to Mayer (2007), individual differences are important factors that can contribute to the development of burnout and lead to second language (L2) learners' academic failure. Individual differences in L2 learning, such as foreign language aptitude, motivation, and personality can have an important effect on language learning (Dörnyei \& Skehan, 2003). Thus, it is important to identify the factors which can predict student burnout in order to avoid their L2 academic failure and improve L2 learning. A need is felt to focus on the effect of Iranian EFL university students' personality on their burnout, which is the focus of this study. Based on the Myers-Briggs test inventory, there are 16 possible types of personality. The present study focuses on four dimensions of personality: extroversion/introversion (E-I), sensation/intuition (S-N), thinking/feeling (T-F), and judgment/perception (J-P).

\section{Literature review}

Most studies have focused on burnout in workplaces and in the human services, such as health care, social work, and legal services (Schaufeli, Leiter, Maslach, 2008). Many researchers have investigated the effect of burnout on practitioners in different occupations (e.g., Maslach, Schaufeli \& Leiter, 2001, Montero-Marín, et al. 2011; Schwarz, 2006). As an example, Lasebikan and Oyetunde (2012) examined the effect of burnout among nurses in a Nigerian general hospital, and they found that a high level of burnout was identified in $39.1 \%$ of the respondents in the area of emotional exhaustion, $29.2 \%$ in the area of depersonalization, and $40.0 \%$ in the area of reduced personal accomplishment. Multivariate analysis of their study showed that doctor/nurse conflict, inadequate nursing personnel, poor wages, high nursing hierarchy, and too frequent night duties were the most important predictors of burnout. In another study, Abdulghafour, Bo-hamrab, Al-Randic, Kameld, and Shazly (2011) examined burnout syndrome among physicians working in primary health care centers in Kuwait and found that emotional exhaustion and depersonalization had lower 
percentage scores than personal accomplishment. They also found that involvement, place of work, job, and income had a significant association with three dimensions of burnout.

Moreover, there are some studies related to physical health and burnout. In his study on staff burnout, Freudenberge (1974) stated that feeling of exhaustion and fatigue, frequent headaches, gastrointestinal disturbances, sleeplessness, and shortness of breath were the impacts of burnout on physical health. Baka (2015) investigated the effect of job demands on physical and mental health. The results of his study indicated that job demands had a negative impact on mental and physical health and this issue increased job burnout.

There are not many studies related to student burnout, but several researchers have focused on burnout among students. Aypay and Sever (2015) conducted a study on 728 high school students in Turkey. The findings demonstrated that the school burnout which students experienced varied in relation to such variables as gender, grade point average, and grade level. In another study, Ghanizadeh and Jahedizadeh (2015) investigated de-motivators, burnout, and language achievement in an Iranian EFL context. They used a de-motivation scale and Maslach burnout inventory questionnaires to explore the relationship among the Iranian students' de-motivation, their burnout, and achievement. The results revealed that the students' de-motivation positively predicted their burnout, and burnout influenced language achievement negatively.

In their study, Sichambo, Maragia, and Simiyu (2012) focused on the causes of burnout. They reported that factors such as students' indiscipline, poor work environment, lack of teaching resources, and lack of support from administration were the main causes of teachers' burnout.

However, the role of personality types in student burnout is missing in the literature. The theory of personality types was first recommended by Jung in 1971. In Jung's theory, there are four principal psychological functions by which humans experience the worldsensation, intuition, feeling, and thinking (Sharp, 1987). Myers-Briggs theory is the developed form of Jung's theory. According to Myers (1980), there are eight psychological functions: extravert, introvert, sensing, intuitive, thinking, feeling, judging, and perceiving. In the introversion/extroversion type, extroverts tend to focus their perception and judgement on people and objects, but introverts tend to focus on concepts and ideas. In the sensing/intuition type, sensing (S) reports observable facts or happenings through one or more of the five senses, but intuition $(\mathrm{N})$ reports meanings, relationships or possibilities that have been worked out beyond the reach of the conscious mind. In the thinking/feeling type, a person who prefers thinking $(\mathrm{T})$ decides based on logical consequences, but the person who prefers feeling $(\mathrm{F})$ 
decides based on personal or social values. In the judging/perceiving type, a person who prefers judgement $(\mathrm{J})$ has reported a preference for using a judgement process for dealing with the outside world, but a person who prefers perception has reported a preference for using a perceptive process for dealing with the outside world (Myers \& McCaulley, 1985; cited in Grace, 1997).

Most studies on personality are related to the impact of personality on people's life. As an example, Komulainen et al. (2014) investigated the effect of personality on daily-life emotional processes. They identified personality traits of a five-factor model by using the NEO five-factor inventory (Costa \& McCrae, 1985). They used hierarchical linear modeling to analyze the effect of the personality traits on daily emotional processes. The results of this study showed that the personality features independently predicted different aspects of daily emotional processes.

Bal and Sahin (2011) focused on the impact of women's personality traits and some sociodemographic variables on quality of life in a sample of 320 Turkish women. The results showed that higher levels of introversion and higher levels of neuroticism led to a lower quality of life among postmenopausal women.

In a different study, Carrell, Prince, and Astika (1996) examined relationships between the personality types of a group of English as a foreign language (EFL) students in Indonesia. They found that there were few direct relationships between learners' personality types and their language performance.

In another study, Carrell (1995) investigated the relationship between writers' personalities and raters' personalities. He chose the writers from native English-speaking university freshman composition students and raters from native English-speaking university freshman composition instructors. He discovered that the personality types of writers affected their scores, and the personality types of raters affected the ratings they give to essays. However, there was no significant relationship between writers' styles and raters' styles.

There are not many studies related to the effect of Iranian EFL university students' personality on their burnout. However, Sulea, Beek, Sarbescu, Virga, and Schaufeli (2015) examined the relations between three different kinds of well-being-engagement, boredom, burnout - and personality in a sample of 255 Romanian social and economic science college students and found that certain personality factors played a role in well-being, but the fulfillment of the needs for autonomy, competence, and relatedness were more important. In another study, Cano-Garcia, Padilla-Munoz, and Carrasco-Ortiz (2005) explored the role of personality and contextual variables in teachers' burnout. The results of their study 
emphasized the important role of personality and some contextual variables such as awareness of professional prestige, kind of personal relationship with the students, and length of working day.

Due to the lack of sufficient research on the effect of EFL students' personality on their burnout in the context of Iran and the important role of personality and burnout in education and students' success, the present study investigated the impact of Iranian EFL university personality types on their burnout. In light of the above issue, the present study has addressed the following research question: Is there any significant difference in Iranian EFL university students' burnout dimensions (emotional exhaustion, cynicism, and efficacy) due to their personality types (extraversion/introversion, sensation/intuition, thinking/feeling, and judgment/perception)?

\section{Method}

A sample of 292 undergraduate students majoring in English translation, English literature, and teaching of English participated in this study. The participants were selected based on convenience sampling from Shahrekord university $(n=68)$, Sheikh Bahaei university $(n=$ 167), and Najafabad Islamic Azad university $(n=57)$.

Two instruments were used for data collection in this study: Maslach Burnout Inventory-Student Survey (MBI-SS) and Myers-Briggs Type Indicator (MBTI). MBI-SS was used to collect data about the level of burnout in students. It consists of 15 items with three subscales: emotional exhaustion including 5 items, depersonalization including 4 items, and personal accomplishment including 6 items. The items of this questionnaire are rated on a 7point Likert scale ranging from 0 (never) to 6 (always). High scores of emotional exhaustion and depersonalization and low scores on personal accomplishment indicate burnout. Items related to personal accomplishment are scored in reverse order. The reliability and validity of MBI-SS are well-established (Schaufeli et al., 2002).

MBTI is a self-report questionnaire designed to indicate psychological preferences in how people perceive the world around them and make decisions (Bowman, 1990; Heimlich, 1990; Luh, 1990). It is based on the typological theory proposed by Carl Jung. MBTI (Form G), translated and validated by Mahmoodian (2008), was used to identify the personality type and personality profile of the participants. It consists of 92 items and each item has two options. This test is made of four different categories including introvert or extrovert, sensing 
or intuitive, thinking or feeling, judging or perceptive, with each category consisting of 23 items.

First, the two main constructs of the study, MBI-SS and MBIT, were briefly explained to participants. The participants were assured that their personal information would be kept confidential and as a reward the results about their personality types would be sent to them. Then, the questionnaires were distributed among participants. After filling in the questionnaires, the data were analyzed by running $t$-test through SPSS (version 22) to answer the research question.

\section{Results}

The research question was intended to seek whether there was any significant difference between Iranian EFL university students' burnout dimensions (emotional exhaustion, depersonalization, personal accomplishment) due to their personality types. To answer this question, independent $t$-tests for students with different personality types were calculated. Table 1 displays $t$-test for extrovert-introvert groups in terms of three dimensions of burnout. 
Table 1. $t$-test between introvert and extrovert groups

\begin{tabular}{|c|c|c|c|c|c|c|}
\hline & & \multicolumn{2}{|c|}{$\begin{array}{c}\text { Levene's Test for } \\
\text { Equality of } \\
\text { Variances }\end{array}$} & \multicolumn{3}{|c|}{ t-test for Equality of Means } \\
\hline & & $F$ & Sig. & $t$ & $d f$ & Sig. (2-tailed) \\
\hline \multirow[t]{2}{*}{$\mathrm{EE}$} & $\begin{array}{l}\text { Equal } \\
\text { variances } \\
\text { assumed }\end{array}$ & .01 & .92 & -23.76 & 290 & .000 \\
\hline & $\begin{array}{l}\text { Equal } \\
\text { variances not } \\
\text { assumed }\end{array}$ & & & -23.30 & 249.90 & .000 \\
\hline \multirow[t]{2}{*}{$\mathrm{DP}$} & $\begin{array}{l}\text { Equal } \\
\text { variances } \\
\text { assumed }\end{array}$ & .03 & .86 & -22.11 & 290 & .000 \\
\hline & $\begin{array}{l}\text { Equal } \\
\text { variances not } \\
\text { assumed }\end{array}$ & & & -21.76 & 254.18 & .000 \\
\hline \multirow[t]{2}{*}{ PA } & $\begin{array}{l}\text { Equal } \\
\text { variances } \\
\text { assumed }\end{array}$ & 1.72 & 19 & -19.05 & 290 & .000 \\
\hline & $\begin{array}{l}\text { Equal } \\
\text { variances not } \\
\text { assumed }\end{array}$ & & & -19.28 & 283.43 & .000 \\
\hline
\end{tabular}

Note. EE $=$ Emotional Exhaustion; $\mathrm{DP}=$ Depersonalization; $\mathrm{PA}=$ Personal Accomplishment

According to Table 1, there was a significant difference between extroverts and introverts in emotional exhaustion $(p=.000)$, depersonalization $(p=.000)$, and personal accomplishment dimensions $(p=.000)$.

Table 2 demonstrates $t$-test results between the sensing-intuition groups for the three burnout dimensions (emotional exhaustion, depersonalization, and personal accomplishment). 
Table 2. $t$-test between sensing and intuition groups

\begin{tabular}{|c|c|c|c|c|c|c|}
\hline & & \multicolumn{2}{|c|}{$\begin{array}{l}\text { Levene's Test } \\
\text { for Equality of } \\
\text { Variances }\end{array}$} & \multicolumn{3}{|c|}{ t-test for Equality of Means } \\
\hline & & $F$ & Sig. & $t$ & $d f$ & Sig. (2-tailed) \\
\hline \multirow[t]{2}{*}{$\mathbf{E E}$} & $\begin{array}{l}\text { Equal } \\
\text { variances } \\
\text { assumed }\end{array}$ & 5.97 & 0.15 & 6.10 & 290 & .000 \\
\hline & $\begin{array}{l}\text { Equal } \\
\text { variances not } \\
\text { assumed }\end{array}$ & & & 6.08 & 281.19 & .000 \\
\hline \multirow[t]{2}{*}{ DP } & $\begin{array}{l}\text { Equal } \\
\text { variances } \\
\text { assumed }\end{array}$ & 7.98 & .005 & 6.28 & 290 & .000 \\
\hline & $\begin{array}{l}\text { Equal } \\
\text { variances not } \\
\text { assumed }\end{array}$ & & & 6.23 & 273.37 & .000 \\
\hline \multirow[t]{2}{*}{$\mathbf{P A}$} & $\begin{array}{l}\text { Equal } \\
\text { variances } \\
\text { assumed }\end{array}$ & 1.00 & .31 & 4.86 & 290 & .000 \\
\hline & $\begin{array}{l}\text { Equal } \\
\text { variances not } \\
\text { assumed }\end{array}$ & & & 4.89 & 289.78 & .000 \\
\hline
\end{tabular}

As Table 2 displays, there was a significant difference in emotional exhaustion $(p=$ $.000)$, depersonalization area $(p=.000)$, and personal accomplishment $(p=.000)$ dimensions between Iranian EFL students who had sensation and intuition personality types.

Table 3 shows $t$-test between thinking-feeling groups for their burnout dimensions. 
Table 3. $t$-test between thinking and feeling groups

Note. $\mathrm{EE}=$ Emotional Exhaustion; $\mathrm{DP}=$ Depersonalization; $\mathrm{PA}=$ Personal Accomplishment

\begin{tabular}{|c|c|c|c|c|c|c|}
\hline & & \multicolumn{2}{|c|}{$\begin{array}{l}\text { Levene's Test } \\
\text { for Equality of } \\
\text { Variances }\end{array}$} & \multicolumn{3}{|c|}{ t-test for Equality of Means } \\
\hline & & $F$ & Sig. & $t$ & $d f$ & Sig. (2-tailed) \\
\hline \multirow[t]{2}{*}{$\mathbf{E E}$} & $\begin{array}{l}\text { Equal } \\
\text { variances } \\
\text { assumed }\end{array}$ & .47 & .49 & -.69 & 290 & .480 \\
\hline & $\begin{array}{l}\text { Equal } \\
\text { variances not } \\
\text { assumed }\end{array}$ & & & -.69 & 286.11 & .490 \\
\hline \multirow[t]{2}{*}{ DP } & $\begin{array}{l}\text { Equal } \\
\text { variances } \\
\text { assumed }\end{array}$ & 2.53 & .11 & -.51 & 290 & .600 \\
\hline & $\begin{array}{l}\text { Equal } \\
\text { variances not } \\
\text { assumed }\end{array}$ & & & -.51 & 289.94 & .600 \\
\hline \multirow[t]{2}{*}{$\mathbf{P A}$} & $\begin{array}{l}\text { Equal } \\
\text { variances } \\
\text { assumed }\end{array}$ & 2.05 & .15 & .47 & 290 & .630 \\
\hline & $\begin{array}{l}\text { Equal } \\
\text { variances not } \\
\text { assumed }\end{array}$ & & & .47 & 283.72 & .630 \\
\hline
\end{tabular}

According to Table 3, there was no significant difference in emotional exhaustion ( $p=$ $.480)$, depersonalization $(p=.600)$, and personal accomplishment $(p=.630)$ dimensions between Iranian EFL university students who had thinking and feeling personality types.

Table 4 indicates $t$-tests between the judging-perceiving groups for their burnout dimensions. 
Table 4. $t$-test Between Judging and Perceiving Groups

\begin{tabular}{|c|c|c|c|c|c|c|}
\hline & & \multicolumn{2}{|c|}{$\begin{array}{l}\text { Levene's Test for } \\
\text { Equality of } \\
\text { Variances }\end{array}$} & \multicolumn{3}{|c|}{ t-test for Equality of Means } \\
\hline & & $F$ & Sig. & $t$ & $d f$ & Sig. (2-tailed) \\
\hline \multirow[t]{2}{*}{$\mathbf{E E}$} & $\begin{array}{l}\text { Equal } \\
\text { variances } \\
\text { assumed }\end{array}$ & .11 & .74 & -2.26 & 290 & .020 \\
\hline & $\begin{array}{l}\text { Equal } \\
\text { variances not } \\
\text { assumed }\end{array}$ & & & -2.27 & 288.85 & .020 \\
\hline \multirow[t]{2}{*}{ DP } & $\begin{array}{l}\text { Equal } \\
\text { variances } \\
\text { assumed }\end{array}$ & .19 & .66 & -1.99 & 290 & .040 \\
\hline & $\begin{array}{l}\text { Equal } \\
\text { variances not } \\
\text { assumed }\end{array}$ & & & -1.98 & 287 & .040 \\
\hline \multirow[t]{2}{*}{ PA } & $\begin{array}{l}\text { Equal } \\
\text { variances } \\
\text { assumed }\end{array}$ & 2.27 & .13 & -1.67 & 290 & .090 \\
\hline & $\begin{array}{l}\text { Equal } \\
\text { variances not } \\
\text { assumed }\end{array}$ & & & -1.67 & 280.27 & .09 \\
\hline
\end{tabular}

Note. EE $=$ Emotional Exhaustion; DP $=$ Depersonalization; PA = Personal Accomplishment

According to Table 4 , there was a significant difference in emotional exhaustion $(p=$ .020) and depersonalization $(p=.040)$ dimensions between Iranian EFL students who had judging and perceiving personality types, but there was not a significant difference in personal accomplishment dimension $(p=.09)$ between Iranian EFL university students who had judging and perceiving personality types

\section{Discussion}

The results of the present study revealed that there was a significant difference between extroverts-introverts and sensing-intuition groups in all dimensions of burnout. As Baab (2009) states, introverts experience more stress than extroverts because they do not use as many coping strategies as extroverts. Extroverts like to interact with other people while introverts prefer to be alone; Introvert EFL students feel overwhelmed when they deal with a lot of learners and this can cause stress. Thus, they can be vulnerable to burnout experience. Moreover, As Duff (2017) points out, sensitive students like to know the facts and details 
whereas intuitive students are open to varieties. Therefore, sensitive EFL students may experience more stress and burnout experience.

One of the findings of this study is that the feeling of exhaustion because of study demands, negative feelings and emotional detachment from realities in the classroom was higher in the EFL students with the feeling personality type than the students with the thinking personality type, but, as expected, the feeling of competence and high achievement, and sense of efficacy in their study was higher in the EFL students with the thinking personality type. However, the difference was not high enough to be significant. That is to say, there was no significant difference between thinking and feeling groups in three dimensions of burnout. This is in agreement with previous studies that showed the degree of burnout experience in thinking and feeling personality types was not very different (Baab, 2009). Both are vulnerable to burnout experience when they get angry very quickly, behave in an irrational manner, lose their sense of commitment and feel inconsistency in their behavior.

Furthermore, one of the findings of the present study was that there was a significant difference between judging-perceiving groups in the emotional exhaustion. The difference in emotional exhaustion between the two groups is noticeable because exhaustion is the central quality of burnout and the most obvious manifestation of this complex syndrome; when people talk about burnout they often refer to experiencing emotional exhaustion (Maslach, Schaufeli, \& Leiter, 2001). Based on the results of the study, students with perceiving personality types are more susceptible to burnout. This can have negative effects on their behavior and learning. These students are more sensitive and problematic for the teacher, and this creates problems for their teacher in the classroom.

In sum, the findings of the present study confirm those of previous studies (e.g., Kim, Shin, \& Umbreit, 2007; Magnano, et al, 2015; Alarcon et al, 2009) which highlight the role of personality types in shaping and developing burnout. As Khan (2011) states, feelings of burnout cannot be separated from individuals' personality type. Personality can intensify the influence of stress, anxiety, reduced self-esteem involved in burnout experience. EFL students with introversion, sensing, and perceiving personality types can experience more emotional exhaustion, depersonalization, and personal accomplishment.

\section{Conclusion and implications}

Iranian EFL university students who exhibit burnout can negatively affect their teachers as well as the atmosphere of the class. EFL university students' lack of motivation might cause 
teachers' lack of motivation. When students exhibit burnout, they become more difficult to teach and this can create problems for their teachers. This study provides helpful information for EFL teachers. The results of this study suggest that personality type is an important factor in developing burnout and might help EFL teachers to develop teaching strategies and techniques so that they meet the needs of their learners with different personality types.

The results of this study can give teachers some predictive power, too. That is to say, they can predict which students will be more at risk and have a tendency to experience burnout. They can recognize those students who are more aggressive, sensitive and impatient in carrying out their duties in the classroom, pay more attention to them, and help them prevent burnout.

Furthermore, the above results imply that EFL university students need to be aware of their personality type, and realize their strength and weak points to decrease their burnout. A personality is able to intensify the effects of negative aspects involved in burnout experience. The findings provide EFL students with helpful insights about their own personalities and help them become better language learners by encouraging coping strategies to prevent burnout. Also, policy makers and educators should provide more attention on the language learners' differences and apply more scrutiny on university students' personality. They should try to find the major sources of stress and burnout and use strategies to reduce them.

\section{References}

Abdulghafour, Y. A., Bo-hamrab, A. M., Al-Randic, M. S., Kameld, M. I., \& El-Shazly, M. K. (2011). Burnout syndrome among physicians working in primary health care centers in Kuwait. Alexandria Journal of Medicine, 47(4), 351-357. DOI: http://doi.org/10.1016/j.ajme.2011.08.004

Alarcon, G., Eschleman, K. J., \& Bowling, N.A. (2009). Relationship between personality variables and burnout: A meta-analysis. Work \& Stress: An International Journal of Work, Health \& Organisations, 23(3), 244-263. DOI: http://doi.org/10.1080/02678370903282600

Aypay, A., \& Sever, M. (2015). School as if a workplace: Exploring burnout among high school students. Journal of Theory and Practice in Education, 11(2), 460-472.

Baab, L. (2009). Type and burnout. Retrieved from http://www.lynnebaab.com/articles/typeand-burnout 
Baka, L. (2015). Does job burnout mediate negative effects of job demands on mental and physical health in a group of teachers? Testing the energetic process of job demandsresources model. International Journal of Occupational Medicine and Environmental Health, 28(2), 335-346. DOI: http://doi.org/10.13075/ijomeh.1896.00246

Bal, M. D., \& Sahin, N. H. (2011). The effects of personality traits on quality of life. Menopause, 18(12), 1309-1316. DOI: http://doi.org/10.1097/gme.0b013e31821e2494

Bowman, A.M. (1990). The effect of the similarity between teacher personality type and student personality type of students' achievement in a community college setting. Unpublished doctoral dissertation, George Peabody College for Teachers of Vanderbilt University.

Braden, J. P. (1995). Intelligence and personality in school and educational psychology. In D. H. Saklofske \& M. Zeidner (Eds.), International handbook of personality and intelligence (pp. 621-650). New York: Plenum.

Cano-Garcia, F. J., Padilla-Munoz, E. M., \& Carrasco-Ortiz, M. A. (2005). Personality and contextual variables in teacher burnout. Personality and Individual Differences, 38, 929-940. DOI: http://doi.org/10.1016/j.paid.2004.06.018

Carrell, P. L. (1995). The effects of writers' personalities and raters' personalities on the holistic evaluation of writing. Assessing Writing, 2, 153-190. DOI: http://doi.org/10.1016/1075-2935(95)90011-x

Carrell, P. L., Prince, M. S., \& Astika, G. G. (1996). Personality types and language learning in an EFL context. Language Learning, 46(1), 75-99. DOI: http://doi.org/10.1111/j.1467-1770.1996.tb00641.X

Costa, P. T. Jr., \& McCrae, R. R. (1985). The NEO personality inventory manual. Odessa, FL: Psychological Assessment Resources.

Dennis, M. M. (2008). Relationship between teacher personality type and burnout in rural middle school teachers. Electronic Theses \& Dissertations, 280-281.

Dörnyei, Z., \& Skehan, P. (2003). Individual differences in second language learning. In C. J. Doughty \& M. H. Long (Eds.), The handbook of second language acquisition, (pp. 589631). Malden: Blackwell Publishing.

Duff, V. (2017). Personality types that experience job burnout. Retrieved from http://work.chron.com/personality-types-experience-job-burnout-5210.html

Freudenberger, H. J. (1974). Staff burn-out. Journal of Social Issues, 90(1), 159-165. DOI: http://doi.org/10.1111/j.1540-4560.1974.tb00706.x 
Ghanizadeh, A., \& Jahedizadeh, S. (2015). De-motivators, burnout, and language achievement in an Iranian EFL context. Journal of Teaching Language Skills, 34(3), 6185. DOI: http://doi.org/10.22099/JTLS.2015.3585

Grace, C. (1997). Personality type, tolerance of ambiguity, and vocabulary retention in CALL. CALICO Journal, 15(1-3), 19-46. DOI: http://doi.org/10.1558/cj.v15i1-3.19-45

Greenberg, M. T., Weissberg, R. P., O’Brien, M. U., Zins, J. E., Fredericks, L., Resnik, H., \& Elias, M. J. (2003). Enhancing school based prevention and youth development through coordinated social, emotional, and academic learning. American Psychologist, 58,466474. DOI: http://doi.org/10.1037/0003-066x.58.6-7.466

Heimlich, J.E. (1990). Measuring teaching style: A correlational study between the Van Tilburg/Heimlich Sensitivity Measure and the Myers-Briggs Personality Indicator on adult educators in central Ohio (unpublished doctoral dissertation). The Ohio State University, Columbus, $\mathrm{OH}$.

Higgins, D. M., Peterson, J. B., \& Pihl, R. O. (2007). Prefrontal cognitive ability, intelligence, Big Five personality, and the prediction of advanced academic and workplace performance. Journal of Personality and Social Psychology, 9(3), 298-319. DOI: http://doi.org/10.1037/0022-3514.93.2.298

Khan, S. (2011). Relationship of job burnout and type a behavior on psychological health among secretaries, International Journal of Business and Management, 6, 31-38. DOI: http://doi.org/10.5539/ijbm.v6n6p31

Khattak, Z. I., Jamshed, T., Ahmad, A., \& Baig, M. N. (2011). An Investigation into the Causes of English Language Learning Anxiety in Students at AWKUM. ProcediaSocial and Behavioral Sciences, 15, 1600-1604. DOI: http://doi.org/10.1016/j.sbspro.2011.03.337

Kim, H.J., Shin, K.H., Umbreit, W.T., Hotel job burnout: The role of personality characteristics, Hospitality Management, 26,421-434. DOI: http://doi.org/10.1016/j.ijhm.2006.03.006

Komulainen, E., Meskanen, K., Lipsanen, J., Lahti J. M., Jylhä, P., Melartin, T., Wichers, M., Isometsä, E., \& Ekelund, J. (2014). The effect of personality on daily life emotional $\begin{array}{llll}\text { processes. } & \text { ONOS } & \text { 230-235. } & \text { DOI: }\end{array}$ http://doi.org/10.1371/journal.pone.0110907

Lasebikan, V. O., Oyetunde, M. O. (2012). Burnout among nurses in a Nigerian general hospital: Prevalence and associated factors. Retrieved from https://www.ncbi.nlm.nih.gov/pmc/articles/PMC3350958/ 
Luh, S.P. (1990). A study of learning styles, personality types, and brain hemispheric preferences of teacher education programs. Unpublished doctoral dissertation, Drake University, Iowa.

Magnano, P., Paolillo, A., \& Giacominelli, B. (2015). Dispositional optimism as a correlate of decision-making styles in adolescence. SAGE Open, 5(2), 13-26. DOI: http://doi.org/10.1177/2158244015592002

Maslach, C. (1982). Burnout: The cost of caring. Englewood Cliffs, NJ: Prentice Hall.

Maslach, C. (1993). Burnout: A multidimensional perspective. In W. B. Schaufeli, C. Maslach, \& T. Marek (Eds.), Professional burnout: Recent developments in theory and research (pp. 19-32). Washington, DC: Taylor and Francis.

Maslach, C. (2015). Psychology of burnout. International Encyclopaedia of the Social and Behavioral Sciences, 2(2), 929-932. DOI: http://doi.org/10.1016/b978-0-08-097086$\underline{8.26009-1}$

Maslach, C., Leiter, M. P., \& Schaufeli, W. B. (2008). Burnout: 35 years of research and practice. Career Development International, 14(3), 204-220. DOI: http://doi.org/10.1108/13620430910966406

Maslach, C., Schaufeli, W. B., \& Leiter, M. P. (2001). Job Burnout. In S.T. Fiske, D. L. Schacter, \& C. Zahn-Waxler (Eds.), Annual Review of Psychology (pp. 397-422). Palo Alto: Annual Reviews.

McPherson, B. (1999). Correlating students' personality types with their rating of topics covered in business communication classes. Business Communication Quarterly, 62(3), 46-53. DOI: http://doi.org/10.1177/108056999906200305

Montero-Marín, J., García-Campayo, J., Fajó-Pascual, M., Carrasco, J. M., Gascón, S., Gili, M., \& Mayoral-Cleries, F. (2011). Sociodemographic and occupational risk factors associated with the development of different burnout types: The Cross-sectional University of Zaragoza Study. BMC Psychiatry, 11(49), 476-490. DOI: http://doi.org/10.1186/1471-244X-11-49

Mayer, J. D. (2007). Asserting the definition of personality. The Online Newsletter for Personality Science, 1, 1-4.

Myers, I. B. (1980). Introduction to Type. Palo Alto, CA: Consulting Psychologists Press, Inc.

Noftle, E. E., \& Robins, R. W. (2007). Personality predictors of academic outcomes: Big five correlates of GPA and SAT scores. Journal of Personality and Social Psychology, 93, 116-130. DOI: http://doi.org/10.1037/e514412014-495 
Pishghadam, R. \& Sahebjam, S. (2012). Personality and emotional intelligence in teacher burnout. The Spanish Journal of Psychology, 15(1), 227-236. DOI: http://doi.org/0.5209/rev_sjop.2012.v15.n1.37314

Ramist, L. (1981). College Students attrition and retention. Findings (ETS), 6, 1-4.

Schwarz Cook, S. L. (2006). Explaining burnout: A mixed method investigation of information technology workers. Unpublished doctoral dissertation, University of Capella.

Sharp, D. (1987). Personality types: Jung's model of typology. Toronto, ON: Inner City Books.

Sichambo, M. N., Maragia, S. N., Simiyu, A. M. (2012). Causes of burnout among secondary school teachers: A case of Bungoma North District-Kenya. International Journal of Academic Research in Progressive Education and Development, 1(4), 195-202.

Sulea,C., Beek, I. V., Sarbescu, P., Virga, D., \& Schaufeli W. B. (2015). Engagement, boredom, and burnout among students: Basic need satisfaction matters more than personality traits. Learning and Individual Differences, 42, 132-138. DOI: http://doi.org/10.1016/j.lindif.2015.08.018

Yang, H. (2004). Factors affecting student burnout and academic achievement in multiple enrolment programs in Taiwan's technical-vocational colleges. International Journal of Educational Development, 24, 283-301. DOI: http://doi.org/10.1016/j.ijedudev.2003.12.001

\section{Author information}

Ali Roohani is Associate Professor of Applied Linguistics, Shahrekord University, Shahrekord, Iran.

Email: roohani.ali@gmail.com

Yeganeh Esmaeili is has an M.A TEFL from Shahrekord University, Shahrekord, Iran.

Email: yeganeh.esmaeeli.30@gmail.com

Masoud Rahimi Domakani is Associate Professor of Applied Linguistics, Shahrekord University, Shahrekord, Iran.

Email: rahimi@lit.sku.ac.ir

To cite this article:

Roohani, A., Esmaeili, Y., \& Rahimi Domakani, M. (2018). The impact of Iranian EFL university students' personality type on their burnout. Bellaterra Journal of Teaching \& Learning Language \& Literature, 11(3), 87103. DOI: http://doi.org/10.5565/rev/jt13.742

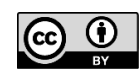

